\title{
The Defense against Antisemitism: Minor Victories, Major Defeats, 1890-1939
}

Since I wrote this paper in the summer of 2018, I have found myself wondering if its title constitutes a just judgment on nearly 130 years of struggle by Jews and non-Jews to eliminate organized antisemitism. Surely, if I had subtitled it "Major Victories, Minor Defeats," we would have to ask ourselves about the purpose of this great conference. Antisemitism, ever-changing, ever-threatening, is still very much with us. What I was wondering about instead was whether we can speak of even minor victories, and, more generally, whether the history of the fight against organized antisemitism during many decades has anything useful to teach us today. I believe that this history and both the victories and defeats are still instructive.

First some clarifications, beginning with the coining of the term: I have not been able to find the use of the word antisemitism before 1860, when it was employed in a cultural rather than a political sense. By late 1879, the German journalist and political activist Wilhelm Marr seized upon the word antisemite as a way of distinguishing his political agenda from traditional Christian Judeophobia and from the commonplace prejudices of his day, thus hoping to give his views the aura of a scientifically derived truth, the product of his personal experience and historical research.

Important to note about the early history of antisemitism is how rapidly what was essentially a neologism achieved the broadest currency. There must have existed a perceived need for a new word to describe the resurgence of conflicts between Jews and the peoples among whom they lived, fondly thought to be nearly overcome in this age of progress but which in fact were becoming ever more openly expressed. The need for a new word affected not just self-identified antisemites but Jews, non-Jewish critics, and neutral bystanders throughout Europe and wherever Europeans settled in the world. The word appeared in titles of books and pamphlets and on the mastheads of newspapers in English, French, Italian, Hungarian, Dutch, and Russian-all by 1894 and in places where no organized antisemitism existed, as well as where it was developing into fullfledged political movements. Even to outsiders, something new seemed to be agitating the vexed relations between Jews and others. ${ }^{1}$

1 For the early history of the term, see R. S. Levy, "Antisemitism, Etymology of," in Antisemitism: A Historical Encyclopedia of Prejudice and Persecution, ed. R. S. Levy (Santa Barbara: ABC-

Ә OpenAccess. () 2021 Richard S. Levy, published by De Gruyter. (cc) BY-NC-ND This work is licensed under the Creative Commons Attribution-NonCommercial-NoDerivatives 4.0 International License. 
Certainly, some periods in Jewish history were characterized by oppression and violence before the 1880s. What was markedly different about this new phenomenon, however, was the swift institutionalization of antisemitism in political parties, grassroots organizations, lobbying agencies, newspapers, learned journals, and a variety of voluntary associations. In the past, persecution had been episodic; outbursts of terrible violence alternated with long periods of quiet relations between Jews and their neighbors. Now, since the emergence of organized antisemitism in the 1880s, the action programs aimed at Jews, buttressed by modern mass media and new technologies, were being played out in the political life of nations; the announced intention of the movement was to continue the struggle for as long as it took to solve the "Jewish Question."2

When it was no longer just a matter of ancient prejudice-what people said or thought about Jews-and had become a question of what they intended to do about them, an organized response among Jews and non-Jews took shape. It is not surprising that the first systematic, nationally focused, defense efforts emerged in Germany, where the organized antisemitic movement experienced its first successes. The following essay concentrates on this specific history because it was and remained the most important, setting precedents in the response to antisemitic assaults in many places. It remains significant because anti-antisemitism's successes and failures in Germany were replicated elsewhere in subsequent years.

It bears mentioning here that, while I do not give great weight to all-toocommon Jew-hatred in my understanding of antisemitism, the importance of casual prejudice among large parts of the population cannot be discounted. Without this reservoir of animosity and suspicion, there would be no constituency for those who wanted to act against Jews. This essay does not address anti-Jewish feeling because no organized defense against antisemitism has ever been able to conquer popular anti-Jewish sentiment, and, in fact, very few have even tried. Therefore, the focus here will be on the exploiters of popular Jew-hatred and the efforts to disarm them.

It took several years for Jews in Germany to formulate a response to the sustained threat against their rights and well-being. A number of historically based attitudes and experiences first had to be overcome. For example, the tortuous granting and withdrawing of legal equality for German Jews during the first

Clio Press, 2005), 1:24-25. On Marr see M. Zimmermann, Wilhelm Marr: The Patriarch of AntiSemitism (New York: Oxford University Press, 1986).

2 See R. S. Levy, "Setting the Pattern," in The Downfall of the Anti-Semitic Political Parties in Imperial Germany (New Haven: Yale University Press, 1975). Expectations of just how long it would take to vanquish the Jews varied greatly among antisemitic activists. 
half of the nineteenth century helped keep them in perpetual insecurity. When Emancipation came in 1869, it was not because of a popular mandate or the result of an imaginary Jewish power but a gift from the liberal-minded North German Reichstag. Like their antisemitic enemies, many Jews believed that Jewish emancipation was conditional, a contractual agreement. Civil equality, according to this view, was not essentially an inalienable right. Jewish emancipation had come because many non-Jews had finally recognized their worthiness. Implicit in emancipation, to German Jews, was the faithful fulfillment of their side of the contract-continuing to be exemplary citizens and demonstrating the ability to become good Germans. In their anxiety to show themselves good Germans, however, Jews hesitated to defend their own cause, concerned about appearing to non-Jews as a special interest group that needed protecting. To make a fuss would only give more ammunition to the antisemites. To ask openly for special intervention by the state would be tantamount to asking for a privileged status, akin to that enjoyed by "court Jews" of earlier centuries. Many were reluctant even to concede that Jews were the real target of antisemitism, theorizing that it was really a matter of displaced social protest, or an attack on liberalism, or on modernity in general. ${ }^{3}$ Many of the problems German Jews wrestled with before entering an active struggle against antisemitism were replicated in France, Austria, Britain, and America. The compelling reason for not launching a frontal attack on their enemies was a general lack of confidence in the sympathies of the mass of their fellow citizens. This remains an issue today, and it still influences Jewish self-defense efforts.

During the 1880s, Jews in Germany made relatively slight responses to antisemitic attacks. Individuals, speaking for themselves, repeatedly countered the more infamous pamphlets of the antisemites. Part of the problem of mounting a collective defense, however, was the fragmentation of the Jewish community. Only antisemites were certain that Jews always and everywhere constituted a monolith. In fact, there was no acknowledged spokesperson, no agreement about what constituted Jewish identity, or how to meet the antisemitic threat. This was not only true of Germany. In defending themselves, Jews have nowhere in the modern world ever spoken with one voice.

For the most part, Jews were willing to rely on the good offices of "unimpeachably objective" Christian defenders. There were an impressively large number of such individuals willing to speak out against the "deeply shameful ... ra-

3 For a brief but illuminating discussion of the concept of antisemitism as "displaced social protest,” see S. Rohrbacher, “The 'Hep-Hep’ Riots of 1819: Anti-Jewish Ideology, Agitation, and Violence," in Exclusionary Violence: Antisemitic Riots in Modern German History, ed. C. Hoffmann et al. (Ann Arbor: University of Michigan Press, 2002), 24-27. 
cial hatred and fanaticism of the Middle Ages."4 But the help of liberal-minded Christians had its problems. For just one example, Theodor Mommsen, the great historian of Rome, had helped write the Declaration of Notables, quoted above, and then worked to gather signatures for it. He was also instrumental in rallying liberal professors at the University of Berlin, isolating Heinrich von Treitschke, after the latter's hostile “A Word about Our Jews," in 1879. But for Mommsen, as for many non-Jews who had supported Jewish equality, from Christian von Dohm onward, the ideal solution to the Jewish Question was the disappearance of Judaism. ${ }^{5}$ Barbaric and shameful as it was for Mommsen and many others, antisemitism was most harmful in its retardation of complete Jewish assimilation, that is, the abandonment of Jewish identity. The alliance between German and Jewish liberals who carried on the fight against antisemitism was always burdened by this reality. ${ }^{6}$ Although liberal ambivalence about the legitimacy of Judaism and a tendency to sometimes wish aloud that Jews would behave themselves a little better and thus disarm the antisemites, their courageous struggle against antisemitism and for a rational politics was valued and appreciated by Jewish activists. Certainly, German Christians had nothing to gain by standing with Jews against those who would deny them their rights and impugned their allegiance to Germany.

When the first avowed antisemite was elected to the Reichstag in 1887, and when he was joined by fifteen others in the elections of 1893, the "silence of the Jews"-a situation much lamented by the already existing, largely Christian and liberal, Verein zur Abwehr des Antisemitismus [Association for the Defense against Antisemitism]-the hesitancy to act in their self-defense, in as united a way as possible, was finally overcome. The Centralverein deutscher Staatsbürger jüdischen Glaubens [Central Association of German Citizens of Jewish Faith] began to take shape in 1893, ultimately becoming the largest Jewish voluntary association in Germany, with approximately 100,000 individual and corporate members.

4 Quotation from the "Declaration of 75 Notables against Antisemitism" (Berlin NationalZeitung, November 12,1880). Among the signatories were Theodor Mommsen, Rudolph von Gneist, and Rudolf Virchow. Original text and English translation can be found at http://ghdi.ghi-dc. org/sub_document.cfm?document_id=1803, accessed June 5, 2020.

5 The Prussian official, Christian von Dohm (1751-1820), advocated Jewish emancipation in a two-volume work (1781); it inaugurated a vigorous debate on the status of Jews in civil society. See R. Liberles, “Dohm's Treatise on the Jews: A Defence of the Enlightenment," Leo Baeck Year Book 33 (1988): $29-42$.

6 See A. T. Levenson, Between Philosemitism and Antisemitism: Defenses of Jews and Judaism in Germany, 1871-1932 (Lincoln: University of Nebraska Press, 2004). For a translation of Treitschke's essay, see R. S. Levy, ed., Antisemitism in the Modern World: An Anthology of Texts (Lexington: D. C. Heath, 1991), 69-73. 
Their credo was clear: "We are not German Jews but German citizens of Jewish faith." The organization asked for no other protection than that afforded to all law-abiding citizens and committed itself to a public defense of Judaism, to a dignified assimilation, and to full participation in German life. ${ }^{7}$

The Centralverein developed a strategy that served as something of a paradigm for Jewish self-defense in countries wherever Jews had constitutional rights, recourse to the courts, and access to the public sphere, that is where they had meaningful options with which to defend themselves against the disenfranchisement and marginalization that organized antisemitism sought to impose. The fight against the antisemites took a three-pronged approach: the publication and broad distribution of apologetic and enlightenment literature; intervention in national, state, and municipal elections on behalf of antiantisemitic candidates; and judicial pursuit of antisemitic libels against Judaism and/or the Jewish community. All three approaches were problematic.

The voluminous literature produced by the Abwehr-Verein and the Centralverein (henceforth $\mathrm{CV}$ ) should have been sufficient to convince any fair-minded person that Jews as a group were excellent citizens, wholly committed to Germany, and valuable contributors to German science, literature, music, economic life, politics, and philanthropy. But, of course, after centuries of denigration, the accumulated sediment of folk wisdom, and culturally embedded suspicions, it was the rare German (or European) who could be described as "openminded" on the Jewish Question. That the systematic, heavily documented refutation of libels and calumnies-the existence of a Jewish secret government, Judeo-Bolshevism, parasitism, ritual murder, treason-was produced by Jews and the "dupes" of Jews was grounds enough for many to reject the literature out of hand. In any case, the effectiveness of this aspect of the anti-anti publishing program was at best dubious. It probably only spoke to those who already did not have to be persuaded that Jews were largely okay. On the other hand, the "enlightenment" literature produced by the two organizations-evidencebased and usually utterly reliable-was relentless in its pursuit of the wrongdoings of the antisemites. The Abwehr-Verein's weekly and the CV's monthly newspapers, a raft of pamphlets, specialized publications, and educational lectures stigmatized the antisemites' true motives, their run-ins with the law, their vicious internal rivalries, their lack of competence as legislators, their hypocrisy, and

7 For the complexities of the development of a Jewish response to antisemitism in Germany, see I. Schorsch, Jewish Reactions to German Anti-Semitism, 1870-1914 (New York: Columbia University Press, 1972). 
their damage to Germany's reputation abroad-all this may well have had a greater impact on the general public than trying to change minds about Jews.

In the imperial era, at least, respectability counted for something. The antisemites themselves constantly felt it necessary to reassure the public of their uprightness and seriousness of purpose. "Rowdy antisemitism" was pushed to the periphery of the mainstream movement; rowdy individuals, such as the infamous Hermann Ahlwardt, were shunned as an embarrassment. Another indication of the effectiveness of the efforts to expose the disgracefulness of antisemitism is how much time and effort antisemitic individuals, parties, and organizations spent trying to discredit the Abwehr-Verein as "lackeys of the Jews" and "Jewish auxiliaries." While the Abwehr-Verein was dismissed as a mere pawn of the Jews, the $C V$ was taken much more seriously from its beginnings until its dissolution in the Third Reich. ${ }^{8}$

The second approach called for intervention into electoral politics. This was not unknown in other national arenas, but nowhere was it as systematically and openly pursued as in Germany by both the $C V$ and the Abwehr-Verein. The $A b$ wehr-Verein created a press service to provide German newspapers and parliamentarians with accurate information about antisemitic candidates and their agendas. Members sitting for the closely allied left-liberal parties took on the antisemites in the Reichstag and valiantly tried to get the German government to honor its own constitution when it came to the rights of Jewish citizens to serve in the civil service or as military officers. In 1912, the two organizations formed a unified election fund to support candidates willing to oppose antisemitism, even Social Democrats-a serious concession for these staunchly bourgeois-liberal defense groups. Such overt intervention in the electoral process was rare elsewhere. In the United States, by contrast, both the Anti-Defamation League of the B'nai B'rith and the American Jewish Committee preferred working from behind the scenes. Theirs was a Fabian version of anti-antisemitism in that it avoided direct involvement with the electorate and sought instead to influence the influential. Ironically, they placed much less faith in the American electorate's healthy instincts than did the German organizations. ${ }^{9}$

8 On the Abwehr-Verein, see B. Suchy, "The Verein zur Abwehr des Antisemitismus (I): From Its Beginnings to the First World War," Leo Baeck Yearbook 28 (1983): 205-39. On the vilification of the Centralverein in the imperial era, see Schorsch, Jewish Reactions to German Anti-Semitism. For Weimar, see D. Walter, Antisemitische Kriminalität und Gewalt: Judenfeindschaft in der Weimarer Republik (Bonn: Verlag J.H.W. Dietz Nachf, 1999), 96, 99 and n. 15.

9 See V. S. Woeste, "American Jewish Committee and Antidefamation Efforts in the United States," in Antisemitism: A Historical Encyclopedia of Prejudice and Persecution, ed. R. S. Levy (Santa Barbara: ABC-Clio Press, 2005), 1: 16-17. 
The Centralverein and the Abwehr-Verein cooperated and, in many ways, duplicated each other's efforts-with one exception. The CV's unique weapon was its legal bureau. The abundant legal talent in the organization combed virtually the entire antisemitic press and analyzed reports from rank and file members of its 177 chapters about the antisemites' misdeeds. This information went into the CV's newspaper but also to its legal bureau. The bureau prepared cases against those who libeled the Jewish community or incited others to racial or religious hatred but only rarely defended individuals or individual communities. This tool's effectiveness was heavily dependent on the good will of the German judiciary and other state agencies, none of which were very scrupulous about implementing equal rights for Jews. Nonetheless, the $C V$ obtained several convictions against leading and lesser antisemites who alleged the defilement of meat by Jewish butchers, the torture of animals by kosher slaughterers, and the "religious necessity" for Jews to commit perjury and ritual murder. Sometimes the bureau achieved its goal by merely informing the proper state authority of an illegality. As a result of such information, the Prussian minister of the interior frequently confiscated antisemitic newspapers, pamphlets, and postcards. Without going to court, the $C V$ brought the attention of officials to the slanders of state institutions in the antisemitic press. Almost all the major antisemites in the imperial era were convicted of various illegalities, and most of these cases were the result of $C V$ intervention. True, the penalties were not terribly severe. For example, Theodor Fritsch, a stalwart of the movement until his death in 1933, was convicted on eight separate occasions for various libels during the imperial era, without ever feeling the need to curb his antisemitic activities. ${ }^{10}$ But the damage to "antisemitism's good name" and the draining of the antisemites' limited resources should be counted as at least minor successes. ${ }^{11}$

At this point, it is perhaps fair to make a very broad generalization: the $C V$ and Abwehr-Verein strategies won some important victories before World War I, helping to quarantine the antisemites in the Reichstag-there were only six of them left in a body of 397 after the elections of 1912. The antisemitic parties had not come close to passing a single law limiting the rights of Jews. Their inability to win over sizable numbers of Catholics and workers, insulated from organized antisemitism (if not anti-Jewish prejudices) by the Center Party and SPD, spoke to the movement's isolation in larger German society. The defense organ-

10 Walter, Antisemitische Kriminalität und Gewalt, 90-93.

11 Count Reventlow, one of the few antisemites of the Imperial era to play a significant role in Weimar and the Third Reich, regarded the $C V$ as far more effective than the Abwehr-Verein, singling out especially its legal and press bureaus. See his Judas Kampf und Niederlage in Deutschland: 150 Jahre Judenfrage (Berlin: Berlin Zeitgeschichte-Verlag, 1940), 368-69. 
izations' constant harassment of powerful groups outside of parliament that made use of antisemitism for a variety of purposes was also seen to have paid off. By 1914, several of these seemed to be backing away from the use of antisemitism as a tool of mobilization. It should be said to the credit of the defense groups' leaders that they refrained from declaring victory-an end to antisemitism, to coin a phrase. They spoke of containment, not an end to the struggle. The unstoppable march of progress would finish the job. But at the very least, the disarray of organized antisemitism on the eve of the Great War had the effect of validating the tools and strategies developed by the Centralverein and the $A b$ wehr-Verein.

These were the same tools and strategies employed during the Weimar Republic, where they miscarried abysmally. We can learn something from this failure.

The Centralverein's performance in the republican era has been frequently criticized as unimaginative, as not proactive enough, as blindly committed to its prewar strategies. None of these criticisms are wholly warranted. And none are totally without a grain of truth. ${ }^{12}$ However, a fair-minded judgement has to take into consideration two big changes in postwar Germany: the political, social, and cultural environment in which antidefamation efforts operated; and an antisemitism much more radicalized by the lost war.

Clearly, the tried-and-true tools of the prewar years were not up to the altered postwar context. Enlightenment literature, still produced in great volume, now had to show a more skeptical public that Jews were not only good citizens, honest businessmen, contributors to, not exploiters of, German culture. The task now was to prove that Jews had not unleashed the World War, or stage-managed the Bolshevik Revolution, or that they were, as several prominent world leaders and hundreds of rabble-rousers claimed, engaged in a world conspiracy to enslave gentiles at any cost. ${ }^{13}$ That German Jews served at the front, fired their

12 For a largely positive view, see A. Paucker, Der jüdische Abwehrkampf gegen Antisemitismus und Nationalsozialismus in den letzten Jahren der Weimarer Republik (Hamburg: Leibniz, 1969); an at times hostile evaluation, written as the destruction of the German Jewish community was being carried out, is A. Doskow and S. B. Jacoby, "Anti-Semitism and the Law in Pre-Nazi Germany," Contemporary Jewish Record 3 (1940): 498-509. A balanced, not uncritical, view is D. Niewyk, The Jews in Weimar Germany (Baton Rouge: Louisiana State University Press, 1980), chap. 4.

13 The best, most responsible, treatment of the reception of The Protocols of the Elders of Zion, the primary vehicle of the Jewish world conspiracy, is E. Horn and M. Hagemeister, eds., Die Fiktion von der jüdischen Weltverschwörung: $\mathrm{Zu}$ Text und Kontext der "Protokolle der Weisen von Zion” (Göttingen: Wallstein, 2012). 
weapons at Jews of other nations, died in the same numbers, and won as many Iron Crosses (proportionately) as other Germans proved a difficult sell. In a world where conspiracy thinking seemed, for a great many people, the best way of explaining the massive disruptions in an age of crisis, dispassionate studies based on empirical evidence, reasoned argument, and respect for one's audience were powerless. ${ }^{14}$

The Centralverein struggled on and, far from becoming passive or remaining mired in the past, it showed a willingness to try new measures and step up its interventions. It reached out to the Catholic Bavarian People's Party regionally and the SPD nationally. While both proved valuable allies, for neither of these parties was fighting antisemitism a top priority. The CV's enlightenment literature dispensed with some of its more gentlemanly self-restraint and began using the no-holds-barred rhetoric of its enemies. Earlier than most, it recognized the Nazi threat as the most serious. Its once most significant weapon, however, the pursuit of antisemites through the judicial system, lost its potency in the chaos of the Republic. A conviction in the Kaiser's courts had carried with it a certain stigma; it could damage and sometimes even end the careers of antisemites. A conviction in the courts of the "Jew Republic," on the other hand, was effectively exploited as a badge of honor by Nazis and other radical right antisemites. It was proof of the power of the Jews and their ruthlessness that honest Germans, trying to save their country from extinction, were fined or jailed, martyrs to the truth.

The $C V$, mindful of this danger, nonetheless brought forward major suits in every year of the Republic-sometimes in opposition to its own rank and file members, who were worried about the reaction of the public to this sort of “pushiness.” Even though the Republic's judiciary was somewhat more inclined than the Kaiser's to accept $C V$-initiated suits, it is difficult to see much of a positive effect. Once again an apt example is Theodor Fritsch, who was convicted eight times during the imperial era-and had not all that much to say about it then-was convicted a further nine times after the war-and never stopped talking about his victimization as evidence of malign Jewish power. Among antisemites, the convictions of their leaders became a credential, evidence of their courage to continue the struggle at any cost. Weimar legal institutions did not have enough authority in the eyes of the general public to make them effective weapons against organized antisemitism. The lesson here is that without a stable state

14 See B. E. Crim, Antisemitism in the German Military Community and the Jewish Response, 1914-1938 (Lanham: Lexington, 2014). 
structure, found to be legitimate in the eyes of most of its citizens, a judiciallybased defense against antisemitism has little prospect of even limited success. ${ }^{15}$

The second change that rendered anti-antisemitism relatively helpless was in the nature of organized antisemitism itself. In a milieu radically altered by war and revolution, violent antisemitism-in word and deed-came to dominate the Weimar Republic. The Nazis and their many rivals on the radical right spoke and wrote openly of murder, assaulted Jews in the streets, vandalized their businesses, desecrated cemeteries and synagogues, and reviled the laws and institutions of the Republic, as they did so. There had been radical outliers among the antisemites of the imperial era, but the great majority were conventional in their outlook, convinced that legal changes, legally arrived at, could solve the Jewish Question. Not many of them were left by the 1920s; they had been supplanted by activists who scorned such conventional notions of the way to fight the Jews. They debated among themselves the virtues of "Pogromantisemitismus" and rejected parliamentary solutions as hopelessly naïve.

The Centralverein was not intellectually or physically equipped to engage with this new sort of antisemitism. The number of people willing to act against Jews was greater; the number willing to have others act in their name was also greater. The CV's erstwhile liberal allies became intimidated and started falling away during the end-phase of the Republic. The Abwehr-Verein eventually voluntarily disbanded. The $C V$ 's publications aimed specifically at well-meaning nonJews lost subscribers and, at the end, could not even be delivered in plain brown wrappers. For the first time since the emergence of organized antisemitism in the 1880s, the Jews were without influential gentiles to defend them.

And this sad fact constitutes the second lesson to be learned from the German case study. The Centralverein certainly knew that without the engagement of German society, there was no winning the battle against antisemitism. Whatever Jews said then and say today in their self-defense, no matter how moderately expressed, evidence-based, or intelligently presented, immediately confronts a deeply embedded culture of doubt and denial in a large part of its intended audience. When, by contrast, antisemites like Otto Glagau wrote in the 1870s, claiming 90 percent of the fraudulent bankruptcies that accompanied the Crash of 1873 were perpetrated by Jews, he did not feel the need to cite a shred of hard evidence-he was that confident he would be believed by his readers. In such a prejudicial environment, Jews needed then and still need in the present day allies in the defense of their rights, allies from all walks of society.

15 The best guide to the CV's defense against antisemitism in the Weimar era remains Walter, Antisemitische Kriminalität und Gewalt. 
True, what these people of good will say is also often impugned, but that they have so little to gain by standing up for decency in the public sphere, for rational politics, and for the well-being of their compatriots is plain to see for all but the most jaundiced. In Europe and America, Jews have always had such allies and usually in significant numbers. When they have lost them, when they have been abandoned, their chances of fending off antisemitism shrink to the vanishing point. They cannot do it alone.

Richard S. Levy has taught German history and the history of the Holocaust at the University of Illinois in Chicago since 1971. He is author of The Downfall of the Antisemitic Political Parties in Imperial Germany (Yale, 1975), editor of Antisemitism in the Modern World: An Anthology of Texts (Heath, 1991), Antisemitism: A Historical Encyclopedia of Prejudice and Persecution (2 vols., ABC-Clio, 2005), and with Albert Lindemann, Antisemitism: A History (Oxford, 2010). He has published twenty scholarly articles or chapters in anthologies. He co-founded and edited $\mathrm{H}$ Antisemitism, an internet electronic discussion forum, from 1993 to 2004.

\section{Bibliography}

Crim, Brian E. Antisemitism in the German Military Community and the Jewish Response, 1914-1938. Lanham: Lexington, 2014.

Doskow, Ambrose, and Sidney B. Jacoby. "Anti-Semitism and the Law in Pre-Nazi Germany." Contemporary Jewish Record 3 (1940): 498-509.

Horn, Eva, and Michael Hagemeister, eds. Die Fiktion von der jüdischen Weltverschwörung: Zu Text und Kontext der "Protokolle der Weisen von Zion." Göttingen: Wallstein, 2012.

Levenson, Alan T. Between Philosemitism and Antisemitism: Defenses of Jews and Judaism in Germany, 1871-1932. Lincoln: University of Nebraska Press, 2004.

Levy, Richard S. "Antisemitism, Etymology of." In Antisemitism: A Historical Encyclopedia of Prejudice and Persecution, edited by Richard S. Levy, 1:24-25. Santa Barbara: ABC-Clio Press, 2005.

Levy, Richard S. Antisemitism in the Modern World: An Anthology of Texts. Lexington: D. C. Heath, 1991.

Levy, Richard S. The Downfall of the Anti-Semitic Political Parties in Imperial Germany. New Haven: Yale University Press, 1975.

Liberles, Robert. “Dohm's Treatise on the Jews: A Defence of the Enlightenment.” Leo Baeck Year Book 33 (1988): 29-42.

Niewyk, Donald L. The Jews in Weimar Germany. Baton Rouge: Louisiana State University Press, 1980.

Paucker, Arnold. Der jüdische Abwehrkampf gegen Antisemitismus und Nationalsozialismus in den letzten Jahren der Weimarer Republik. Hamburg: Leibniz, 1969.

Reventlow, Graf Ernst zu. Judas Kampf und Niederlage in Deutschland: 150 Jahre Judenfrage. Berlin: Berlin Zeitgeschichte-Verlag, 1940. 
Rohrbacher, Stefan. “The 'Hep-Hep' Riots of 1819: Anti-Jewish Ideology, Agitation, and Violence." In Exclusionary Violence: Antisemitic Riots in Modern German History, edited by Christhard Hoffmann, Werner Bergmann, and Helmut Walser Smith, 23-42. Ann Arbor: University of Michigan Press, 2002.

Schorsch, Ismar. Jewish Reactions to German Anti-Semitism, 1870-1914. New York: Columbia University Press, 1972.

Suchy, Barbara. "The Verein zur Abwehr des Antisemitismus (I): From Its Beginnings to the First World War." Leo Baeck Yearbook 28 (1983): 205-39.

Walter, Dirk. Antisemitische Kriminalität und Gewalt: Judenfeindschaft in der Weimarer Republik. Bonn: Verlag J.H.W. Dietz Nachf, 1999.

Woeste, Victoria Saker. "American Jewish Committee and Antidefamation Efforts in the United States." In Antisemitism: A Historical Encyclopedia of Prejudice and Persecution, edited by Richard S. Levy, 1:16-17. Santa Barbara: ABC-Clio Press, 2005.

Zimmermann, Moshe. Wilhelm Marr: The Patriarch of Anti-Semitism. New York: Oxford University Press, 1986. 